GLOTTODIDACTICA XLVIII/2 (2021)

ADAM MICKIEWICZ UNIVERSITY PRESS POZNAN

DOI: $10.14746 / \mathrm{s}$ l.2021.48.2.02

Christine A. JOHNSTON

Rowan University

Gabriella B. Klein

Università degli Studi di Perugia

The Umbra Institute

Key \& Key Communications

NOAH JOHNSTON

Teaching Assistance Program in France, Glassboro

JOEL JOHNSTON

Let Me Learn, Glassboro

\title{
The Interactive Learning Model: A theory that assists the L2 learner in achieving self-awareness
}

\begin{abstract}
This study uses the Interactive Learning Model theory to explore the nature of self-awareness within each of three L2 learners. Using the Learning Connections Inventory (LCI), a validated and reliable learning instrument, each participant identified their combination of learning patterns. The subjects then recalled specific L2 learning experiences, relating them in first person narratives. Next, each subject composed anecdotes and reflections based on their narratives. They also participated in one-on-one interviews in which they described their learning experiences during basic L2 learning activities: vocabulary, grammar, writing, conversation, and passive listening during movies, live theatre, spectator sports, and television. Our analysis of the LCI outcomes and selfreported learning experiences demonstrated that the self-awareness gained from understanding their combination of learning patterns and expanded by the self-reflection activities, increased the participants' ability to articulate the nature of their self-awareness and to identify evidence of their growth in self-awareness during L2 learning.
\end{abstract}

KEYwORDS: self-awareness, metacognition, L2 learning, learning patterns. 


\section{INTRODUCTION}

Learning is crucial to our existence. Centuries ago, ancient literature characterized learning as the wellspring of our existence. However, as ancient literature explains, in order for learning to be maximized, it needs to be used with intention (Proverbs 4.23). In other words, learning needs to develop an individual's ability to become self-aware. A model of learning that teaches learners how to visualize, listen, and respond to the internal workings of their learning mind is the Interactive Learning Model (ILM). Its 25-year application in primary, secondary, university, and adult learning settings suggests that it is a theory that - when implemented with fidelity - results in nimble, effective, efficient, and self-aware learners. The study here reported suggests the Interactive Learning Model also has the potential to enrich the learning experience of L2 learners (Camilleri 2003).

\section{THE FIRST STEP TO SELF-AWARENESS: UNDERSTANDING OUR BRAIN-MIND CONNECTION}

The Interactive Learning Model defines learning as "taking in the world around you and making sense of it" (Johnston 1994). The ILM theory suggests that learning begins when the brain takes in stimuli through our five senses (sight, sound, taste, touch, and smell). Our sensory portals regulate the stimuli entering the brain. Once inside the brain, the stimuli are processed by neuro-receptors and electro-chemicals using all sectors of the brain. However, the stimuli require translation, something to break the electrochemical and neuro-receptor codes. The interpreter-translator is found in the working memory of the mind.

As Figure 1 illustrates, in order to reach the mind, the stimuli must pass through a brain-mind interface and enter the working memory where they are translated into symbolic representations (language, numbers, musical notes, scientific notation, and thousands of other symbols) to be stored and retrieved when needed.

The depiction in Figure 1 represents the brain-mind interface. Note the function that learning patterns play in the interface between the brain and mind. Observe how they filter the stimuli that pass from the brain to the mind. Next, note how the stimuli enter the mind and are translated by the Working Memory into symbolic representation (numbers, letters, musical notes, etc.), and stored in an individual's memory for retrieval. The Interactive Learning theory posits that each learning pattern provides a specific filtering function. A factor analysis of the descriptive data collected from 2,700 children and adults between 1989-1996, 


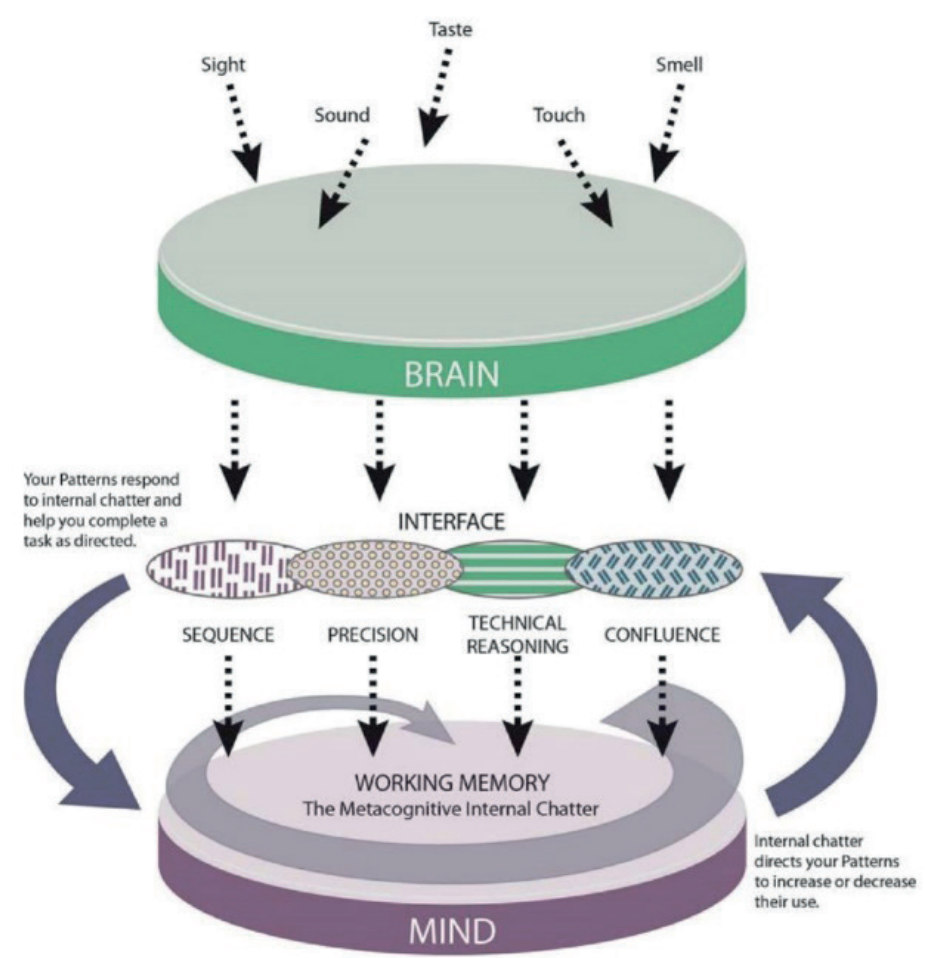

Figure 1. The Brain-Mind Interface $(C$ Source: Johnston (2018: 44).

resulted in the researchers identifying four discrete constructs which were labeled learning patterns and named based on the role and function each played in the filtering process. The labels designated were: Sequence, Precision, Technical Reasoning, and Confluence. Table 1 lists the primary characteristics of each learning pattern. The learning patterns are described in detail (see Tables 2-9).

Table 1. The primary characteristics of each learning pattern

\begin{tabular}{|c|c|c|c|}
\hline Pattern of Sequence & Pattern of Precision & $\begin{array}{l}\text { Pattern of Technical } \\
\text { Reasoning }\end{array}$ & Pattern of Confluence \\
\hline $\begin{array}{l}\text { - Organizes life } \\
\text { - Makes lists } \\
\text { - Lives by schedules } \\
\text { - Makes extensive } \\
\text { plans }\end{array}$ & $\begin{array}{l}\text { - Relishes information } \\
\text { - Seeks facts } \\
\text { - Must be right } \\
\text { - Provides detailed } \\
\text { responses }\end{array}$ & $\begin{array}{l}\text { - Solves problems } \\
\text { - Uses few words } \\
\text { - Looks for relevance } \\
\text { and practicality } \\
\text { - Works alone }\end{array}$ & $\begin{array}{l}\text { - Takes risks } \\
\text { - Sees the big picture } \\
\text { - Embraces innova- } \\
\text { tion } \\
\text { - Initiates change }\end{array}$ \\
\hline
\end{tabular}

Source: Johnston (1998). 


\subsection{A distinguishing feature of the ILM theory}

A distinguishing feature of the ILM theory is its representation of the mental processes which operate within each of the four learning patterns. These mental processes consist of cognition (thinking), conation (doing), and affectation (feeling) (McClean 1978; Snow, Corno \& Jackson 1996). Figure 2 illustrates the interaction occurring among the mental processes of each of the four patterns.

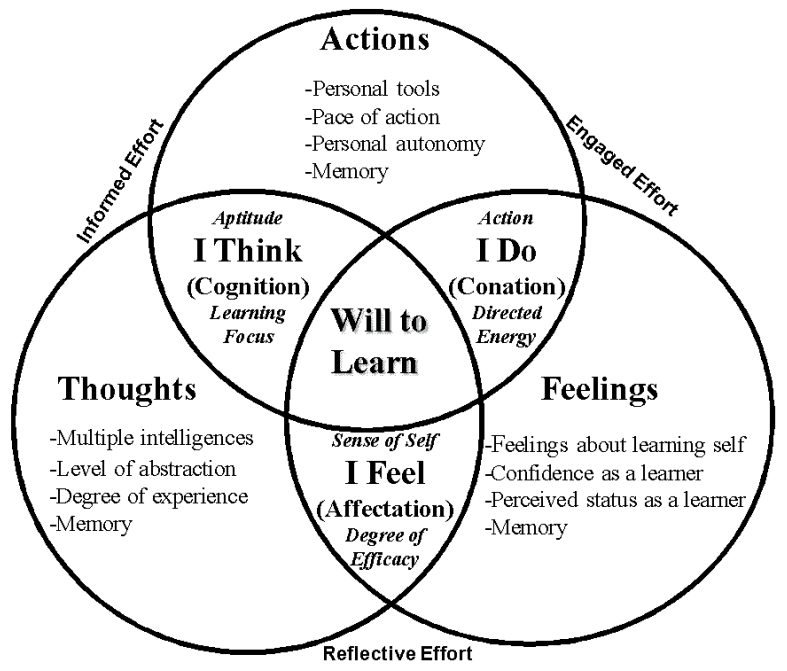

Figure 2. The interaction of mental processes within each learning pattern Source: Johnston (1998: 32).

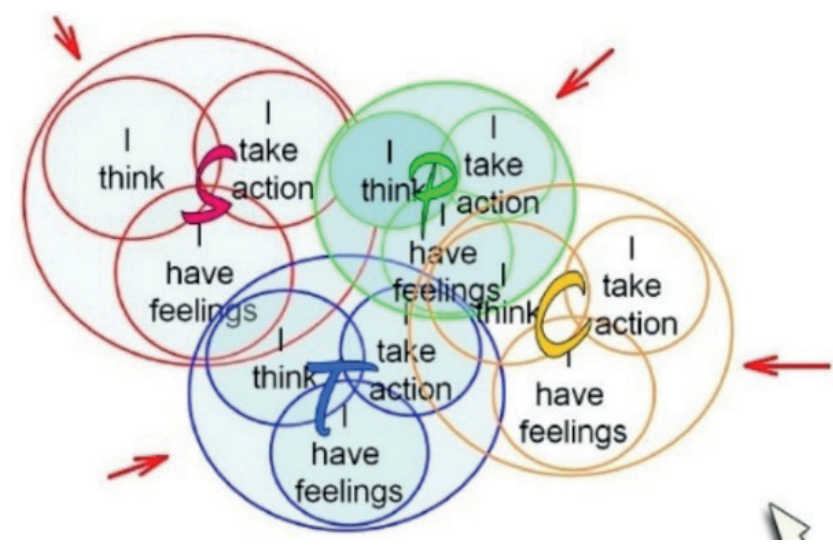

Figure 3. The interaction of all three processes interacting within each of the four learning patterns Source: prepared on the basis of Borkowski, Carr, Rellinger \& Pressley (1990: 53-92). 
Figure 3 represents the synchronous interplay among the four learning patterns and the constructs of cognition, conation, and affectation within each that create a learners' sense of motivation and degree of efficacy (Borkowski, Carr, Rellinger \& Pressley 1990: 53-92).

\subsection{The mental processes that form an individual's sense of self as a learner}

Cognition is the construct of thinking. It is the source of written and spoken communication, the basis of levels of abstraction, and the engine of an individual's reflective thought. Conation is the construct of taking action. It determines an individual's use of tangible and intangible tools. It is the governor of an individual's pace and degree of social interaction. Affectation is the construct of feelings. It is the basis of an individual's sense of value, sense of self, and sense as a learner. It is an individual's emotive barometer (Pattoia 2009).

The instrument that captures an individual's combination of learning patterns, the Learning Connections Inventory (LCI) (Johnston \& Dainton 1997), was developed over a six-year period and involved 2,700 subjects (1800 12-18 yearold students and 900 professional educators in the US, Canada, England, Malta, the Netherlands, Slovenia, Czechia, Italy, Spain, and Australia). Individuals completing the LCI use a five-point scale to respond to each of the 28 self-report items and provide three short-answer free responses. Upon completion of the LCI, individuals receive a set of scores that indicate the range into which their scale scores fall for each of the four learning patterns. The ranges include Use First, Use as Needed, Avoid. Tables 2-9 present the internal thoughts, actions, and feelings of either end of the spectrum.

Table 2. Sequence Pattern Use-First Characteristics

\begin{tabular}{|l|l|l|l|}
\hline \multicolumn{1}{|c|}{$\begin{array}{c}\text { (Cognition) } \\
\text { How you think }\end{array}$} & \multicolumn{1}{|c|}{$\begin{array}{c}\text { (Conation) } \\
\text { How you act }\end{array}$} & \multicolumn{1}{c|}{$\begin{array}{c}\text { (Affectation) } \\
\text { How you feel }\end{array}$} & What you might say \\
\hline $\begin{array}{l}\text { I think in categories } \\
\text { and objectives. }\end{array}$ & $\begin{array}{l}\text { I break tasks into } \\
\text { steps and complete } \\
\text { them in order. }\end{array}$ & $\begin{array}{l}\text { I feel secure when } \\
\text { I have a plan and can } \\
\text { work the plan. }\end{array}$ & $\begin{array}{l}\text { What's the goal for } \\
\text { this? Let's stay on } \\
\text { task! }\end{array}$ \\
\hline $\begin{array}{l}\text { I think with clarity, } \\
\text { not clutter. }\end{array}$ & $\begin{array}{l}\text { I organize my sched- } \\
\text { ule, my workspace, } \\
\text { and my life. }\end{array}$ & $\begin{array}{l}\text { I thrive on a well- } \\
\text { ordered life. }\end{array}$ & $\begin{array}{l}\text { There is a place for } \\
\text { everything and every- } \\
\text { thing in its place. }\end{array}$ \\
\hline $\begin{array}{l}\text { I think in phases: } \\
\text { beginning, middle, } \\
\text { and end. }\end{array}$ & $\begin{array}{l}\text { I do a task from begin- } \\
\text { ning to end without } \\
\text { interruptions. }\end{array}$ & $\begin{array}{l}\text { I feel complete when } \\
\text { I can bring closure to } \\
\text { a task. }\end{array}$ & $\begin{array}{l}\text { Nothing feels better } \\
\text { than crossing an item } \\
\text { off my to-do list. }\end{array}$ \\
\hline
\end{tabular}

Source: Johnston (2010: 39). 
Table 3. Sequence Pattern Avoid Characteristics

\begin{tabular}{|l|l|l|l|}
\hline \multicolumn{1}{|c|}{$\begin{array}{c}\text { (Cognition) } \\
\text { How you think }\end{array}$} & \multicolumn{1}{c|}{$\begin{array}{c}\text { (Conation) } \\
\text { How you act }\end{array}$} & \multicolumn{1}{c|}{$\begin{array}{c}\text { (Affectation) } \\
\text { How you feel }\end{array}$} & What you might say \\
\hline Why practice? & $\begin{array}{l}\text { I avoid directions and } \\
\text { practicing. }\end{array}$ & $\begin{array}{l}\text { I feel I'm wasting my } \\
\text { time. }\end{array}$ & $\begin{array}{l}\text { Do I have to do it } \\
\text { again? }\end{array}$ \\
\hline $\begin{array}{l}\text { These directions make } \\
\text { no sense! }\end{array}$ & $\begin{array}{l}\text { I ignore directions } \\
\text { and written plans, } \\
\text { such as a syllabus. }\end{array}$ & $\begin{array}{l}\text { I feel confused by the } \\
\text { directions. }\end{array}$ & $\begin{array}{l}\text { What do you mean } \\
\text { I have to follow these } \\
\text { directions? }\end{array}$ \\
\hline $\begin{array}{l}\text { Why can't I just jump } \\
\text { in? }\end{array}$ & $\begin{array}{l}\text { I begin a task where } \\
\text { I am most comfort- } \\
\text { able. }\end{array}$ & $\begin{array}{l}\text { I don't feel the need } \\
\text { to start by using only } \\
\text { one entry point. }\end{array}$ & $\begin{array}{l}\text { Does it really matter } \\
\text { what I do first? }\end{array}$ \\
\hline
\end{tabular}

Source: Johnston (2010: 39).

Table 4. Precision Pattern Use-First Characteristics

\begin{tabular}{|l|l|l|l|}
\hline \multicolumn{1}{|c|}{$\begin{array}{c}\text { (Cognition) } \\
\text { How you think }\end{array}$} & \multicolumn{1}{c|}{$\begin{array}{c}\text { (Conation) } \\
\text { How you act }\end{array}$} & \multicolumn{1}{c|}{$\begin{array}{c}\text { (Affectation) } \\
\text { How you feel }\end{array}$} & What you might say \\
\hline I think in information. & $\begin{array}{l}\text { I challenge statements } \\
\text { and ideas that I doubt. }\end{array}$ & I thrive on knowledge. & $\begin{array}{l}\text { I need more informa- } \\
\text { tion. }\end{array}$ \\
\hline $\begin{array}{l}\text { Do I have all the infor- } \\
\text { mation? }\end{array}$ & I ask many questions. & $\begin{array}{l}\text { I feel confident when } \\
\text { I have accurate infor- } \\
\text { mation. }\end{array}$ & What is...? \\
\hline $\begin{array}{l}\text { I leave no piece of } \\
\text { information unread. }\end{array}$ & I write things down. & $\begin{array}{l}\text { I like people to share } \\
\text { information with me. }\end{array}$ & $\begin{array}{l}\text { I am currently reading } \\
\text { three different books } \\
\text { on... }\end{array}$ \\
\hline
\end{tabular}

Source: Johnston (2010: 40).

Table 5. Precision Pattern Avoid Characteristics

\begin{tabular}{|l|l|l|l|}
\hline \multicolumn{1}{|c|}{$\begin{array}{c}\text { (Cognition) } \\
\text { How you think }\end{array}$} & \multicolumn{1}{|c|}{$\begin{array}{c}\text { (Conation) } \\
\text { How you act }\end{array}$} & \multicolumn{1}{c|}{$\begin{array}{c}\text { (Affectation) } \\
\text { How you feel }\end{array}$} & What you might say \\
\hline $\begin{array}{l}\text { Do I have to read all } \\
\text { of this? }\end{array}$ & $\begin{array}{l}\text { I don't have specific } \\
\text { answers. }\end{array}$ & $\begin{array}{l}\text { I am overwhelmed } \\
\text { when confronted with } \\
\text { details. }\end{array}$ & $\begin{array}{l}\text { Don't expect me to } \\
\text { know names and } \\
\text { dates! }\end{array}$ \\
\hline $\begin{array}{l}\text { How am I going to } \\
\text { remember all of this? }\end{array}$ & $\begin{array}{l}\text { I skim instead of read- } \\
\text { ing details. }\end{array}$ & I fear looking stupid. & $\begin{array}{l}\text { Do all these details } \\
\text { matter? }\end{array}$ \\
\hline $\begin{array}{l}\text { Who cares about all } \\
\text { this stuff? }\end{array}$ & $\begin{array}{l}\text { I take few, if any, } \\
\text { notes. }\end{array}$ & $\begin{array}{l}\text { I become frustrated } \\
\text { trying to find the one } \\
\text { right answer. }\end{array}$ & $\begin{array}{l}\text { Stop asking me so } \\
\text { many questions! }\end{array}$ \\
\hline
\end{tabular}

Source: Johnston (2010: 40). 
Table 6. Technical Reasoning Pattern Use-First Characteristics

\begin{tabular}{|l|l|l|l|}
\hline \multicolumn{1}{|c|}{$\begin{array}{c}\text { (Cognition) } \\
\text { How you think }\end{array}$} & \multicolumn{1}{c|}{$\begin{array}{c}\text { (Conation) } \\
\text { How you act }\end{array}$} & \multicolumn{1}{c|}{$\begin{array}{c}\text { (Affectation) } \\
\text { How you feel }\end{array}$} & What you might say \\
\hline $\begin{array}{l}\text { I think of a situation } \\
\text { as a puzzle to be } \\
\text { solved. }\end{array}$ & $\begin{array}{l}\text { I size up the situation } \\
\text { and solve the problem. }\end{array}$ & $\begin{array}{l}\text { I feel satisfaction } \\
\text { when I have solved } \\
\text { a problem. }\end{array}$ & $\begin{array}{l}\text { Good job! Bring on } \\
\text { the next problem. }\end{array}$ \\
\hline $\begin{array}{l}\text { I think: How practical } \\
\text { is this? }\end{array}$ & I look for relevance. & $\begin{array}{l}\text { I feel useful when the } \\
\text { task has purpose. }\end{array}$ & $\begin{array}{l}\text { How will I ever use } \\
\text { this in the real world? }\end{array}$ \\
\hline $\begin{array}{l}\text { I want to know how } \\
\text { something works. }\end{array}$ & $\begin{array}{l}\text { I tinker with the ob- } \\
\text { ject. }\end{array}$ & $\begin{array}{l}\text { I enjoy discovering its } \\
\text { function. }\end{array}$ & What a great design! \\
\hline
\end{tabular}

Source: Johnston (2010: 41).

Table 7. Technical Reasoning Pattern Avoid Characteristics

\begin{tabular}{|l|l|l|l|}
\hline \multicolumn{1}{|c|}{$\begin{array}{c}\text { (Cognition) } \\
\text { How you think }\end{array}$} & \multicolumn{1}{c|}{$\begin{array}{c}\text { (Conation) } \\
\text { How you act }\end{array}$} & \multicolumn{1}{c|}{$\begin{array}{c}\text { (Affectation) } \\
\text { How you feel }\end{array}$} & What you might say \\
\hline $\begin{array}{l}\text { I don't think 'repair', } \\
\text { I think 'replace'. }\end{array}$ & $\begin{array}{l}\text { I avoid using tools or } \\
\text { instruments. }\end{array}$ & I am inept. & $\begin{array}{l}\text { If it is broken, throw } \\
\text { it away! }\end{array}$ \\
\hline $\begin{array}{l}\text { Can anyone help me } \\
\text { figure this out? }\end{array}$ & $\begin{array}{l}\text { I can describe a prob- } \\
\text { lem but struggle to } \\
\text { solve it. }\end{array}$ & $\begin{array}{l}\text { I hate problem solv- } \\
\text { ing. }\end{array}$ & $\begin{array}{l}\text { I'm an educated per- } \\
\text { son; I should be able } \\
\text { to do this! }\end{array}$ \\
\hline $\begin{array}{l}\text { Why do I have to as- } \\
\text { semble this? }\end{array}$ & $\begin{array}{l}\text { I rely on the directions } \\
\text { to help me succeed. }\end{array}$ & $\begin{array}{l}\text { I lack the confidence } \\
\text { to construct things. }\end{array}$ & $\begin{array}{l}\text { I need written direc- } \\
\text { tions not just pictures! }\end{array}$ \\
\hline
\end{tabular}

Source: Johnston (2010: 41).

Table 8. Confluence Pattern Use-First Characteristics

\begin{tabular}{|l|l|l|l|}
\hline \multicolumn{1}{|c|}{$\begin{array}{c}\text { (Cognition) } \\
\text { How you think }\end{array}$} & \multicolumn{1}{|c|}{$\begin{array}{c}\text { (Conation) } \\
\text { How you act }\end{array}$} & \multicolumn{1}{c|}{$\begin{array}{c}\text { (Affectation) } \\
\text { How you feel }\end{array}$} & What you might say \\
\hline $\begin{array}{l}\text { I think: to risk is to } \\
\text { learn. }\end{array}$ & I take risks. & $\begin{array}{l}\text { I am not afraid to risk } \\
\text { and fail. }\end{array}$ & $\begin{array}{l}\text { Nothing ventured; } \\
\text { nothing gained! }\end{array}$ \\
\hline $\begin{array}{l}\text { I think outside the } \\
\text { box. }\end{array}$ & $\begin{array}{l}\text { I brainstorm. I let my } \\
\text { mind wander without } \\
\text { boundaries. }\end{array}$ & $\begin{array}{l}\text { I feel energized by } \\
\text { possibilities that are } \\
\text { still in the idea stage. }\end{array}$ & $\begin{array}{l}\text { I have an idea. No, } \\
\text { wait! I have an even } \\
\text { better idea! }\end{array}$ \\
\hline $\begin{array}{l}\text { I connect things that } \\
\text { are seemingly unre- } \\
\text { lated. }\end{array}$ & $\begin{array}{l}\text { I read over, under, } \\
\text { around, and between } \\
\text { the lines. }\end{array}$ & $\begin{array}{l}\text { I revel in connecting } \\
\text { the dots! }\end{array}$ & Think big picture! \\
\hline
\end{tabular}

Source: Johnston (2010: 42). 
Table 9. Confluence Pattern Avoid Characteristics

\begin{tabular}{|l|l|l|l|}
\hline \multicolumn{1}{|c|}{$\begin{array}{c}\text { (Cognition) } \\
\text { How you think }\end{array}$} & \multicolumn{1}{c|}{$\begin{array}{c}\text { (Conation) } \\
\text { How you act }\end{array}$} & \multicolumn{1}{c|}{$\begin{array}{c}\text { (Affectation) } \\
\text { How you feel }\end{array}$} & What you might say \\
\hline Where is the focus? & I look for the purpose. & I feel unsettled. & Let's stay focused! \\
\hline $\begin{array}{l}\text { What do you mean, } \\
\text { imagine? }\end{array}$ & I avoid the unknown. & My head is in a whirl! & $\begin{array}{l}\text { Where did that idea } \\
\text { come from? }\end{array}$ \\
\hline Who is in control? & $\begin{array}{l}\text { I operate with clear } \\
\text { goals and a single } \\
\text { laser like focus. }\end{array}$ & $\begin{array}{l}\text { No more changes or } \\
\text { surprises, please! }\end{array}$ & This is out of control! \\
\hline
\end{tabular}

Source: Johnston (2010: 42).

Tables 2-9 provide person-specific pattern descriptions (Johnston 2021). Unlike measures of personality, multiple intelligences, or learning styles, the ILM theory identifies the learner's interactive learning patterns and teaches them to use their new self-awareness with intention. The ILM theory accomplishes this by revealing to learners the internal chatter of their learning patterns and then coaching them to use this micro-level of metacognition to manage their learning more effectively.

\subsection{Metacognition: The power to direct learning experiences}

Metacognition is the means by which learners gain their awareness of how to develop and use their learning to the fullest capacity (Flavell 1979). Its use develops a learner's ability to self-regulate, reflect, strategize, and respond appropriately to any learning situation. Brown describes it as "the ability to have insight into your ability to learn intentionally; to reflect and monitor your internal learning activities; that is, to plan, orchestrate, or oversee your own learning efforts" (after Scanlon 2004: 76). Hennessey (1999: 6) contends that metacognition is, "an inner awareness of one's own unobservable learning constructs". As the NRC (1999: 14) reports, "Metacognition often takes the form of an internal conversation... one in which individuals note failures, activate knowledge, plan ahead, and apportion time and memory".

The ILM theory depicts the act of metacognition as the internal talk of an individual's learning patterns as they direct their pattern-centric talk to each other and vie to lead the learning experience. Table 10 depicts the pattern chatter and the interaction of the learning patterns within an L2 learner's mind (Auchère 2021). 
Table 10. The pattern chatter and the interaction of the learning patterns within an L2 learner's mind

\begin{tabular}{|c|c|c|c|c|c|}
\hline $\begin{array}{c}\text { NBA } \\
\text { Degree of } \\
\text { Use and } \\
\text { Scores }\end{array}$ & - & SEQUENCE & PRECISION & $\begin{array}{l}\text { TECHNICAL } \\
\text { REASONING } \\
\text { Use as } \\
\text { Needed }\end{array}$ & CONFLUENCE \\
\hline $\begin{array}{l}\text { Metacogni- } \\
\text { tive Recall }\end{array}$ & $\begin{array}{l}\text { The Task L2 } \\
\text { Application }\end{array}$ & Chatter & Chatter & Chatter & Chatter \\
\hline $\begin{array}{l}\text { What chatter } \\
\text { was occurring } \\
\text { among your } \\
\text { learning pat- } \\
\text { terns? }\end{array}$ & $\begin{array}{l}\text { Carry out } \\
\text { a conversa- } \\
\text { tion and write } \\
\text { in English }\end{array}$ & $\begin{array}{l}\text { This is com- } \\
\text { plicated trans- } \\
\text { lating every } \\
\text { sentence from } \\
\text { French to } \\
\text { English in my } \\
\text { head before } \\
\text { I speak. }\end{array}$ & $\begin{array}{l}\text { I can learn } \\
\text { composition } \\
\text { skills by read- } \\
\text { ing English } \\
\text { subtitles off } \\
\text { the screen! }\end{array}$ & $\begin{array}{l}\text { I don't have } \\
\text { to understand } \\
\text { every word } \\
\text { I'm hearing. } \\
\text { I can under- } \\
\text { stand the } \\
\text { context with } \\
\text { things other } \\
\text { than words. }\end{array}$ & $\begin{array}{l}\text { I can use lyrics } \\
\text { from songs to } \\
\text { learn the lan- } \\
\text { guage! }\end{array}$ \\
\hline
\end{tabular}

Source: based on Auchère (2021).

By having individuals complete pattern tables of this nature, both the instructor and student have a means by which to express their self-awareness. An external expression of pattern speech artifacts allows individuals to bring to light and examine what is driving their response to a given learning experience or activity. Further, it enables them to address their feelings, negotiate or restructure the activity, and resolve any pattern conflicts (Paris \& Winograd 1990). Numerous studies conducted on the effects of the ILM theory on the development of learner self-awareness and academic achievement in STEM (science, technology, engineering and math), and other foundational academic subjects (writing and reading), have reported that students who used their self-awareness as a learner with intention experienced a statistically significant improvement on assessments ranging from high stakes tests to team performance (teams engaged in lab work, engineering competitions, and in-class projects (Ward 2009; Newell, Dahm \& Harvey 2004; McSweeney 2005). These studies suggest that L2 learners might also benefit from the application of the ILM theory to their L2 acquisition experience.

\subsection{Other theories of L2 learning}

A review of other theories of L2 learning found that there is no agreement on how we learn language. While there is no unified conceptualization or robust theory of L2 learning, there are a number of theories that focus on L2 learning. Chief among them is Krashen's 5 Hypotheses (1982) which posit that traditional textbook 
guided L2 learning (Learning) is not effective. Instead, Krashen favors an inductive approach, also described as spontaneous or natural, "learning in situ" as the most effective L2 method (Acquisition) (Johnson 2016). Krashen labels the phases of his 5 Hypotheses Acquisition-Learning, Monitor, Input, Affective Filter, and Natural Orders. After careful review, Krashen's hypotheses leave the reader asking: Where is the science that links these hypotheses to a comprehensive theory of L2 learning? How do these constructs operate at the micro level within the mind of the L2 learner?

Figure 4 illustrates Krashen's Theory of Second Language Acquisition (after Schütz 2019) in chart form juxtaposing the ILM theory against both the traditional approach of L2 Learning against and Krashen's Acquisition hypothesis. By charting the three, the reader can compare how each approach to L2 learning addresses or fails to address how their theory or set of hypotheses increases the L2 learner's growth in self-awareness.

\begin{tabular}{|c|c|c|c|c|}
\hline LEARNING & & INTERACTIVE LEARNING MODEL & & ACQUISITION \\
\hline Artificial & $\longleftrightarrow$ & $\begin{array}{l}\text { Students use their self-awareness of their } \\
\text { learning patterns (mental operations) to } \\
\text { consciously chose the most authentic and } \\
\text { effective L2 learning techniques }\end{array}$ & $\longleftrightarrow$ & Natural \\
\hline Technical & & Intrapersonal and interpersonal & $\leftarrow$ & Personal \\
\hline $\begin{array}{l}\text { Priority on writ- } \\
\text { ten language }\end{array}$ & & $\begin{array}{l}\text { Priority: Use self-awareness } \\
\text { to grow, develop, and succeed in L2 } \\
\text { learning }\end{array}$ & $\longleftrightarrow$ & $\begin{array}{l}\text { Priority on spo- } \\
\text { ken language }\end{array}$ \\
\hline $\begin{array}{l}\text { Theory (lan- } \\
\text { guage analysis) }\end{array}$ & & Interactive Learning Model theory & & $\begin{array}{l}\text { Practice (lan- } \\
\text { guage in use) }\end{array}$ \\
\hline $\begin{array}{l}\text { Formal instruc- } \\
\text { tion }\end{array}$ & & $\begin{array}{l}\text { L2 intentional use of interactive mental } \\
\text { operations }\end{array}$ & $\longleftarrow$ & $\begin{array}{l}\text { Meaningful } \\
\text { interaction }\end{array}$ \\
\hline $\begin{array}{l}\text { Deductive } \\
\text { Teaching (rule- } \\
\text { driven, top- } \\
\text { down) }\end{array}$ & & $\begin{array}{l}\text { Synthesis of deductive and inductive } \\
\text { learning driven by the L } 2 \text { learner rather } \\
\text { than the instructor }\end{array}$ & $\longleftarrow$ & $\begin{array}{l}\text { Inductive coach- } \\
\text { ing (rule-discov- } \\
\text { ery; bottom-up) }\end{array}$ \\
\hline $\begin{array}{l}\text { Conscious pro- } \\
\text { cess }\end{array}$ & & $\begin{array}{l}\text { Metacognitive self-awareness (conscious- } \\
\text { ly listens to the chatter among one's learn- } \\
\text { ing patterns) }\end{array}$ & $\longleftrightarrow$ & $\begin{array}{l}\text { Subconscious } \\
\text { process }\end{array}$ \\
\hline Preset syllabus & & $\begin{array}{l}\text { Combination of preset and improvised } \\
\text { activities }\end{array}$ & $\stackrel{\longleftarrow}{\longleftrightarrow}$ & $\begin{array}{l}\text { Learner-cen- } \\
\text { tered activities } \\
\text { with room for } \\
\text { improvisation }\end{array}$ \\
\hline
\end{tabular}

Figure 4. Where the Interactive Learning Model fits between the traditional and Krashen's L2 learning model 


\section{THE METHODOLOGY OF THE STUDY}

The study reported here examines the cases of three L2 learners (ages 22-60) and explores their growth in self-awareness over a 15-20 year period. It relates their first-hand introduction to L2 learning and traces the growth that led to a more advanced L2 level. Next, the subjects identify how they were introduced to the concept of their learning patterns and how each grew to use them with intention. Finally, each subject provides metacognitively generated reflections on the pattern chatter in their minds. Further, this study provides evidence of the subjects' self-awareness at the ILM micro level. For the sake of participant anonymity, the participants are referred to by means of pseudonyms.

Prior to the study, the participants provided their Learning Connections Inventory (LCI) scores and discussed their understanding of their learning combination. Then three phases of the research followed.

\section{Phase I Personal Narrative}

The study subjects then composed a personal narrative, in which they recounted their benchmark L2 learning experiences in chronological order. They were then asked to expand their initial responses by answering six questions that drilled down on their actual learning experiences. The questions ranged from learning vocabulary and grammar to initial and on-going experiences with oral language (hearing and comprehending the language in music, film, etc.) and through personal interaction.

\section{Phase II Data Analysis}

In Phase II, the subjects analyzed their personal narrative looking for evidence of their learning patterns unobtrusively embedded in their written responses. They colour-coded phrases and single words using a standard ILM protocol for determining which learning pattern it represented. Within their written responses they identified evidence of metacognitive chatter and pattern artifacts. Finally, they reflected on the extent their data reinforced and/or provided them with a greater sense of self-awareness as L2 learners.

\section{Phase III Insights}

In the final phase, the subjects recorded how they currently use their L2 skills in their professional settings. Each identified the extent to which their pattern knowledge and conscious development of their metacognitive skills had heightened the use of their L2 awareness within a professional context.

In the data section which follows, we present data collected from the subject in the order of the phases. 


\section{DATA COLLECTED ${ }^{1}$}

\subsection{NTJ}

NTJ became aware of his learning patterns at age eight. His narrative reflects his degree of metacognitive self-awareness as an L2 learner and teacher. Table 11 reports the degree to which he uses each of his learning patterns as determined by the Learning Connection Inventory.

Table 11. NTJ's LCI Patterns: Measured degree of use

\begin{tabular}{|c|c|c|c|c|c|}
\hline Case ID & Sequence & Precision & $\begin{array}{c}\text { Technical } \\
\text { Reasoning }\end{array}$ & Confluence & $\begin{array}{c}\text { L2 Application/ } \\
\text { Vocation }\end{array}$ \\
\hline NTJ & $\begin{array}{c}\text { Use } \\
\text { as Needed }\end{array}$ & Use First & $\begin{array}{c}\text { Use } \\
\text { as Needed }\end{array}$ & Use First & $\begin{array}{c}\text { L2 Instructor } \\
\text { of English in } \\
\text { French Second- } \\
\text { ary School } \\
\text { (TAPIF) }\end{array}$ \\
\hline
\end{tabular}

NTJ is a native English speaker who explains: I hadn't known much about the French language or culture, and simply chose it by chance as my language requirement. His motivation to accelerate his L2 experience came as a result of his first two semesters (32 weeks) of guided instruction:

During my initial exposure to the French language, I developed a growing interest in the language fueled by my passionate curiosity in linguistics. I actually enjoyed picking apart and re-constructing parts of a language new to me. I resonated with learning the patterns and order of the language. In college, I specialized in studying translation and interpretation. My collegiate language acquisition also included two immersive study abroad experiences: at the Université de Nice Sophia Antipolis in the Faculté de Lettres (2018), and 5 months in Bordeaux at the Université BordeauxMontaigne (2019).

A scenario each participant in the study was asked to respond to was, "Recall the first time you were asked to speak with a native speaker. What was the internal chatter that occurred within your mind?" Table 12 represents NTJ's metacognitive thoughts designated by learning pattern chatter.

${ }^{1}$ The quotations from primary sources, i.e. the narratives and reflections of the examined individuals, are marked in italics. 
Table 12. NTJ's coded responses to Q. 5 Indicating metacognitive pattern chatter

\begin{tabular}{|c|c|c|c|c|c|}
\hline $\begin{array}{l}\text { Metacogni- } \\
\text { tive Recall }\end{array}$ & The Task & $\begin{array}{l}\text { Sequence } \\
\text { Chatter }\end{array}$ & $\begin{array}{c}\text { Precision } \\
\text { Chatter }\end{array}$ & $\begin{array}{l}\text { Technical } \\
\text { Reasoning } \\
\text { Chatter }\end{array}$ & $\begin{array}{l}\text { Confluence } \\
\text { Chatter }\end{array}$ \\
\hline $\begin{array}{l}\text { Reconstruct } \\
\text { what was } \\
\text { occurring } \\
\text { within your } \\
\text { mind the } \\
\text { first time you } \\
\text { spoke to a na- } \\
\text { tive speaker. }\end{array}$ & $\begin{array}{l}\text { I need to ask } \\
\text { the server } \\
\text { a question after } \\
\text { dining. }\end{array}$ & $\begin{array}{l}\text { It's a good } \\
\text { thing I thought } \\
\text { of this scenario } \\
\text { ahead of time. } \\
\text { At least I've } \\
\text { practiced it in } \\
\text { my head. }\end{array}$ & $\begin{array}{l}\text { I know the cor- } \\
\text { rect vocab. I'm } \\
\text { almost certain. } \\
\text { Just use clear } \\
\text { pronunciation } \\
\text { and then listen } \\
\text { carefully to her } \\
\text { response. }\end{array}$ & $\begin{array}{l}\text { Let's be practi- } \\
\text { cal, here. The } \\
\text { server doesn't } \\
\text { care if I'm flu- } \\
\text { ent in French. } \\
\text { Just ask the } \\
\text { question. }\end{array}$ & $\begin{array}{l}\text { I just need to } \\
\text { speak and not } \\
\text { worry about } \\
\text { taking a risk } \\
\text { and embarrass- } \\
\text { ing myself. }\end{array}$ \\
\hline
\end{tabular}

In his narrative, NJT unfolds also on L2 benchmark experiences:

One area of L2 learning that caused frustration was correcting my essays. When I made an inaccurate translation, I'd have my paper returned with sentences underlined and the comment, 'This doesn't sound French.' I would propose other solutions only to have my professor say she 'didn't know what to fix, but that it sounded off'. This used to drive me up the wall because it was a worst-case scenario for both my Use First Precision and my Use First Confluence. I was wrong (Precision), but I couldn't get more information to rectify my error, and my risks (Confluence) hadn't paid off. Then came my opportunities to study abroad and with them came the means to resolve my frustration of not knowing ' what sounded French'. Once in France I was eating, shopping, exploring, and learning, in every sense of the word consuming another language. I started to build an internal grit that resisted the temptation to completely understand a new expression and instead focus more on when and where it's used. I learned to partner the 'learn by experience' aspect of my quietest pattern (Technical Reasoning) with my Use First Precision and identified how the seeds of experience helped my mind make the fine distinctions necessary to be a successful L2 learner. This was a significant moment of self-awareness for me.

With reference to his professional application, NTJ explains:

After college graduation, I was accepted to the Teaching Assistant Program In France (TAPIF) for 2020-2021. Currently, I assist seven English teachers between a vocational high school and a middle school in Orleans, France. I interact with hundreds of L2 learners and am continuously immersed in the language. I seek to use my selfawareness to help them advance in their second-language acquisition. 


\subsection{JT}

JTJ became aware of his learning patterns in graduate school and uses his L2 skills and ILM self-awareness as a part of his interactions with German friends when participating at international conferences. Table 13 represents the degree to which JTJ uses each of his learning patterns as identified by the LCI.

Table 13. JTJ's LCI Patterns: Measured degree of use

\begin{tabular}{|c|c|c|c|c|c|}
\hline Case ID & Sequence & Precision & $\begin{array}{c}\text { Technical } \\
\text { Reasoning }\end{array}$ & Confluence & $\begin{array}{c}\text { L2 Application/ } \\
\text { Vocation }\end{array}$ \\
\hline JTJ & Use First & Use First & Avoid & Avoid & $\begin{array}{c}\text { Executive Director, } \\
\text { of an educational } \\
\text { service, NGO }\end{array}$ \\
\hline
\end{tabular}

JTJ's journey to achieving L2 fluency began in his junior year of high school, when he enrolled in a German class and after one year of traditional foreign language instruction was chosen to spend 12 months in Germany sponsored by the US Congress-German Bundestag Program (USC-GB). After his second month living with his host family, they stopped speaking English - forcing him to speak the language and learn the vocabulary and grammar since his host family had enrolled him in a gymnasium. Within three months of his arrival in Germany, the [Berlin] wall came down and shortly afterwards, he participated in an L2 class on German along with immigrants from Russia and Poland. He surmises that,

learning German with these students was very helpful because we were doing so at a slower pace which meant we could become more familiar with the sounds and where words were breaking. As the year progressed, I suddenly, really got it. I was not fluent, but the language just seemed to slow down for me, and my precision was no longer flustered by the speed of the spoken language.

JTJ's initial experience using his L2 skills is recorded in Table 14 . His metacognitive pattern chatter reveals his use of Sequence to prepare, his desire to be correct, and his concern that he will embarrass himself.

In his narrative, JTJ unfolds also on benchmark experiences:

As I analyze my L2 learning experience through the lens of my ILM self-awareness, I recall my host parents' frustration with me because I was trying to understand every word and by doing so, I was failing to get the big picture. Had I understood my learning patterns, I would have known that my Use First 'need to know every word' Precision was actually preventing me from wrapping my mind around the 
conversation I was hearing. In addition, my Avoid level of Confluence would not let me take the risk of being wrong. Another insight I have had involves my unwillingness to invest in learning German grammar. I used to complain that grammar is so perfunctory, until 20 years later in grad school when my selfawareness kicked in. In my teens, I saw grammar as something very mechanical, represented with diagrams of sentence structures, and, since I Avoid Technical Reasoning, I set myself up to dislike grammar. I also thought grammar was all about rules and exceptions to the rules. What I did not realize was that my same Use First Sequence and Precision that helped me practice and memorize vocabulary could help me see the patterned structure of grammar and memorize those grammar exceptions. As I reflect on that aspect of my L2 development, I recognize that a learning pattern-based strategy could have changed my affective response to learning German grammar.

Table 14. JTJ's coded responses to Q.5 indicating metacognitive pattern chatter

\begin{tabular}{|c|c|c|c|c|c|}
\hline $\begin{array}{l}\text { Metacogni- } \\
\text { tive Recall }\end{array}$ & The Task & $\begin{array}{l}\text { Sequence } \\
\text { Chatter }\end{array}$ & $\begin{array}{c}\text { Precision } \\
\text { Chatter }\end{array}$ & $\begin{array}{l}\text { Technical } \\
\text { Reasoning } \\
\text { Chatter }\end{array}$ & $\begin{array}{c}\text { Confluence } \\
\text { Chatter }\end{array}$ \\
\hline $\begin{array}{l}\text { Reconstruct } \\
\text { what was } \\
\text { occurring } \\
\text { within your } \\
\text { mind the } \\
\text { first time you } \\
\text { spoke to a na- } \\
\text { tive speaker. }\end{array}$ & $\begin{array}{l}\text { Go into the } \\
\text { open-air mar- } \\
\text { ket and pur- } \\
\text { chase an item } \\
\text { (Wiesbaden) }\end{array}$ & $\begin{array}{l}\text { I'll rehearse } \\
\text { what I'm } \\
\text { going to say. } \\
\text { I'd better re- } \\
\text { hearse possi- } \\
\text { ble responses } \\
\text { to the seller } \\
\text { too. }\end{array}$ & $\begin{array}{l}\text { What do } \\
\text { I need to say? } \\
\text { What are they } \\
\text { going to say } \\
\text { back to me? } \\
\text { What if they } \\
\text { use words } \\
\text { I don't know? }\end{array}$ & $\begin{array}{l}\text { I can figure } \\
\text { out how to } \\
\text { build a con- } \\
\text { versation } \\
\text { something } \\
\text { you'd actually } \\
\text { say in a mar- } \\
\text { ket. If I pan it, } \\
\text { I can do it }\end{array}$ & $\begin{array}{l}\text { I've got to } \\
\text { try this. It } \\
\text { probably } \\
\text { won't go very } \\
\text { well. I could } \\
\text { embarrass } \\
\text { myself. }\end{array}$ \\
\hline
\end{tabular}

When taking about his professional application, he explains:

My interest in speaking German has remained high due to my family heritage, interest in travel, and my need to communicate with German speaking friends and business clientele as business opportunities arise. I take pride in working to maintain my L2 fluency by listening to German radio, watching German sports, and reading German news publications.

\subsection{GBK}

GBK became aware of the ILM theory fifteen years ago as a participant in an EU sponsored Grundtvig Project. She uses her ILM self-awareness within her EU sponsored Intercultural Projects (SPICES 2007; RADAR 2016; DREAMM 2021). The degree to which GBK uses each learning pattern is reflected in Table 15. 
Table 15. GBK's LCI patterns: Measured degree of use

\begin{tabular}{|l|l|l|l|l|l|}
\hline Case ID & Sequence & Precision & $\begin{array}{c}\text { Technical } \\
\text { Reasoning }\end{array}$ & Confluence & $\begin{array}{c}\text { L2 Application/ } \\
\text { Vocation }\end{array}$ \\
\hline GBK & Use First & Use First & Use First & Use First & $\begin{array}{l}\text { Coordinator of EU Inter- } \\
\text { cultural } \\
\text { Communication projects }\end{array}$ \\
\hline
\end{tabular}

GBK grew up in a multi-language environment, so it is not surprising that she chose to enter the field of sociolinguistics. In her narrative, she explains

sociolinguistics encompasses many competences: sociology, anthropology, different linguistic approaches... It has quantitative and qualitative approaches; it includes not only theory but also empirical studies; all learning patterns fit perfectly into this panorama, and when you have them all as Use First, I would say you have a big advantage in dealing with this kind of scholarly field.

GBK's narrative was similar to NTJ's and JTJ's in that she was able to identify specific L2 learning experiences where a knowledge of ILM would have helped her wrap her mind around Arabic (which she reflected ran counter to her Sequence, Confluence, and Technical Reasoning as she was not given the opportunity to practice it with native speakers) and Chinese (which was too tedious to learn and required more focus than her Use First Confluence was willing to devote). Table 16 captures GBK's metacognitive chatter decoded by Pattern. Her confidence in her L2 use is clearly represented in her metacognitive pattern chatter in Table 16.

Table 16. GBK's coded responses to Q.5 indicating metacognitive pattern chatter

\begin{tabular}{|l|l|l|l|l|l|}
\hline \multicolumn{1}{|c|}{$\begin{array}{c}\text { Metacogni- } \\
\text { tive Recall }\end{array}$} & The Task & $\begin{array}{c}\text { Sequence } \\
\text { Chatter }\end{array}$ & \multicolumn{1}{|c|}{$\begin{array}{c}\text { Precision } \\
\text { Chatter }\end{array}$} & $\begin{array}{c}\text { Technical } \\
\text { Reasoning } \\
\text { Chatter }\end{array}$ & $\begin{array}{l}\text { Confluence } \\
\text { Chatter }\end{array}$ \\
\hline $\begin{array}{l}\text { Reconstruct } \\
\text { what was } \\
\text { occurring } \\
\text { within your } \\
\text { mind the } \\
\text { first time you } \\
\text { spoke to a na- } \\
\text { tive speaker. }\end{array}$ & $\begin{array}{l}\text { Learn the } \\
\text { sentence and } \\
\text { construction } \\
\text { rules of a lan- } \\
\text { guage. }\end{array}$ & $\begin{array}{l}\text { I can already } \\
\text { form sentenc- } \\
\text { es in this lan- } \\
\text { guage. That } \\
\text { was easy! It's } \\
\text { similar to... }\end{array}$ & $\begin{array}{l}\text { How do you } \\
\text { say...? Really? } \\
\text { I wonder why } \\
\text { they say it } \\
\text { that way? }\end{array}$ & $\begin{array}{l}\text { I can figure } \\
\text { out this lan- } \\
\text { guage. Well, } \\
\text { I have to so } \\
\text { I can do some } \\
\text { basic shop- } \\
\text { ping. }\end{array}$ & $\begin{array}{l}\text { I like talking } \\
\text { to these na- } \\
\text { tive speak- } \\
\text { ers. I'm not } \\
\text { concerned } \\
\text { about making } \\
\text { mistakes. }\end{array}$ \\
\hline
\end{tabular}

GBK's narrative was similar in its examples of L2 benchmark experiences, i.e., her Precision's fear of speaking to native speakers if she were not certain of specific idiomatic distinctions, or her Use First Confluence talking back to her 
Precision stating: I really don't care if I'm making a mistake, I'm not going to worry about it. However, the content of her narrative differed from NTJ's and JTJ's in the degree to which her ILM self-awareness informs her personal and professional life, as she wrote:

Since both my husband and I use all four patterns at the Use First level, we sometimes struggle working together; on the other side, knowing that he is higher in Technical Reasoning and Sequence, while I am higher than him in Precision and Confluence, I better can foresee when we need to integrate our learning patterns to make progress.

GBK's self-awareness also feeds her realization how she manages her EU sponsored intercultural communication projects.

When it comes to her professional application, GBK uses ILM awareness to plan content and activities for the migrant population with whom she works that takes into consideration the combination of learning patterns of her clients and guides her decisions on how to manage and communicate with her clients and project partners:

In all learning/teaching materials, I take into account how learners with very different pattern combinations can use their learning patterns to develop their cultural and language integration. Since all projects revolve around communication (interpersonal and visual) in an intercultural perspective, also considering that the difference in communicating/interacting with others is not only culturally influenced, but also in relationship to one's learning pattern(s).

\section{COMPARATIVE ANALYSIS}

All three subjects have Precision at the Use First level. This is the pattern that values words and their correct usage. In language learning, it would appear that a Use First level of Precision would be to an L2 learner's advantage. Interestingly in this study, each subject found Use First Precision to both assist and detract from different aspects of their L2 learning. In their reflections, each provided examples of how their use of Precision helped them develop their vocabulary; however, each also noted how their Use First Precision caused them frustration. The evidence of this two-fold effect is found in their reflections which follow. As they examined the effects of their other patterns on their Use First Precision, each noted the cumulative effect of these results on their L2 self-awareness. 
NTJ in his personal narrative explains he used his Use First level of Precision to immerse sic (himself) in the basic studying of subjects, objects, verb tenses, and a hearty helping of vocabulary and grammar. He allowed his Use First pattern of Confluence to give his Precision permission to make mistakes with the rationale, so I can learn from it. He hypothesizes that his two Use First learning patterns are the reason for his fascination with translation and interpretation:

Reflecting on this, I recognize that my Precision was nurtured for the first two years of L2 study by learning basic linguistic foundations, but I needed even more details and information, more 'toys' for my Confluence for me to remain engaged and not become bored or grow stagnant so study abroad became an equally essential aspect of my L2 experience.

In contrast, JTJ relates in his narrative that his Use First Precision triggered his initial venture into L2 learning, and he enjoyed using it to learn vocabulary. However, unlike NTJ's use of Precision, JTJ's both helped and frustrated him, particularly when it came to knowing the precise gender of German nouns. His situation was further compounded by his other Use First pattern, Sequence (the pattern of rules and structure). It "wanted" the rules for the gender of nouns to be logical and consistent. Finally, his learning of grammar was stymied because he saw it as requiring the use of Technical Reasoning, a learning pattern he avoided. While JTJ was cognitively capable of memorizing this information, his patterns of Precision, Sequence, and Technical Reasoning negatively affected his willingness to invest the time to do so. JTJ's case presents an example of how a learner's self-awareness of learning patterns could have helped resolve his frustration. Years later, JTJ reflects, I recognize now what a difference knowing my learning patterns would have made in establishing a better attitude toward the learning of the language beyond just vocabulary. I would have applied myself instead of giving up and making do.

Finally, GBK believes it is her Technical Reasoning that motivates her to use sociolinguistics in practical ways to improve people's lives. In her reflection, she posited the following premises:

Premise A: Migrants have difficulties interacting with civil servants / service providers. Premise B: Civil servants / public and private service providers have difficulties interacting with migrants. Private and public service is the intersection where integration of migrants into their new socio-cultural context fails or succeeds. Therefore, I have chosen to use my ILM self-awareness to help migrants learn how to use their learning patterns and to correctly fill out forms and conduct over the counter interactions. This is a concrete approach to solving an intercultural communication problem. It works. It satisfies all my patterns, and it works! 


\section{CONCLUSION}

While many variables affect L2 learning, one factor appears to be more determinative of increasing self-awareness than others - and that is how L2 learners consciously or subconsciously use their learning patterns to metacognitively direct their learning experiences. Clearly three cases are not sufficient to draw broad conclusions; however, this work along with Camilleri's (2003) original study of nineteen L2 learners and the effect of their knowledge of their learning patterns on their academic persistence and achievement, suggests that additional studies are warranted. According to the present study, three principal issues are worth examining: 1) the power and influence of metacognition to accelerate an individual's ability to achieve L2 competency; 2) the long-term effects of knowing one's learning patterns and applying them with intention to real life learning settings (work, coaching, relationships); and the impact on L2 achievement when both instructors, or coaches, or mentors, and their students are aware of their learning patterns and strive to use them with intention.

\section{REFERENCES}

Auchère, N. (2021). Personal interview, February 3, 2021. Orléans.

Borkowski, J.G. / Carr, M. / Rellinger, E. / Pressley, M. (1990). Self-regulated cognition: Interdependence of metacognition, attributions, and self-esteem. In: B.F. Jones / L. Idol (eds.), Dimensions of thinking and cognitive instruction (pp. 53-92). Hillsdale, NJ: Lawrence Erlbaum Associates, Inc.

Camilleri, A. (2003). Learner autonomy in modern language learning: Find your bearing and pick your way. Presented at the LML Summer Institute. Swedesboro, NJ.

Flavell, J. (1979). Metacognition and cognitive monitoring. A new area of psychological inquiry. American Psychologist, 34, 906-911.

Hennessey, M.G. (1999). Probing the dimensions of metacognition: Implications for conceptual changes in teaching and learning. Paper presented at the Annual Meeting of the National Association for Research in Science Teaching (NARST). Boston, MA.

Johnston, C. (1994). The interactive learning model. Paper presented at the meeting of the British Education Research Association. Oxford University, Queen Anne's College, Oxford.

Johnston, C. / Dainton, G. (1997). The learning combination inventory. Thousand Oaks, CA: Corwin.

Johnson, M. (2016). Elements of second language learning. https://www.youtube.com/ watch? $\mathrm{v}=$ CMdseB-EB8Y [access: 15.09.2021].

Klein, G.B. (2007). SPICES GUIDELINES. A training methodology for intercultural communication in institutional settings. Perugia: Key \& Key Communications.

Klein, G.B. (2021). DREAMM - Develop and Realise Empowering Actions for Mentoring Migrants. New ways of bringing together newly arrived Third-Country Nationals and local communities.957882 - DREAMM - AMIF-2019-AG-CALL.

Klein, G.B. / Calleja, C. / Gelfgren, V. / Ravenda, A. (2016). RADAR (Regulating AntiDiscrimination and AntiRacism) Trainers' Manual. Anti-hate communication tools in an intercultural perspective. Deruta / Perugia: Key \& Key Communications. 
Klein, G.B. / Szczepaniak-Kozak, A. (2014). L2 textbook evaluation in view of L2 adult learners' real communication needs: A study of bureaucratic-institutional communication skills. In: E. Wąsikiewicz-Firlej / H.A. Lankiewicz / A. Szczepaniak-Kozak (eds.), Culture and creativity in discourse studies and foreign language pedagogy (pp. 93-115). Piła: Wydawnictwo PWSZ im. S. Staszica w Pile.

Krashen, S.D. (1982). Principles and practice in second language acquisition. Oxford: Pergamon Press.

McSweeney, T. (2005). Merging cognitive and instructional theories: Implementation of an advanced learning system in secondary mathematics. New York: Hofstra University.

National Research Council (NRC) (1999). How people learn: Bridging research and practice. M.S. Donovan / J.D. Bransford, / J.W. Pellegrino (eds.). Washington, DC: The National Academies Press.

Newell, J. / Dahm, K. / Harvey, R. (2004). Developing metacognitive engineering teams. Chemical Engineering Education, Fall 38 (4), 316-320.

Paris, S.G. / Winograd, P. (1990). How metacognition can promote academic learning and instruction. In: B.F. Jones / L. Idol (eds.), Dimensions of thinking and cognitive instruction (pp. 15-51). Hillsdale, NJ: Erlbaum.

Pattoia, M. (2009). Il Let Me Learn Process ${ }^{\circledR}$ come strumento integrabile in un sistema di eLearning adattivo. VEGA - Periodico elettronico di cultura, didattica e formazione, $V$ (3).

Scanlon, E. (2004). Reconsidering science learning. Hove: Psychology Press.

Schütz, R.E. (2019). Stephen Krashen's Theory of second language acquisition. English Made in Brazil. https://www.sk.com.br/sk-krash-english.html [access: 15.09.2021].

Snow, R.E. / Corno, L. / Jackson, D. (1996). Individual differences in affective and conative functions. In: D.C. Berliner / R.C. Calfee (eds.), Handbook of educational psychology (pp. 243-310). New York, NY: Macmillan.

Ward, N. (2009). The influence of a metacognitive learning system on the writing achievement of elementary school students. South Orange, NJ: Seton Hall University.

Received: 31.03.2021; revised: 28.09.2021

\section{CHRISTINE A. JOHNSTON}

Rowan University

johnstca@comcast.net

ORCID: 0000-0002-0732-4513

\section{GABRIELLA B. KLEIN}

Università degli Studi di Perugia

The Umbra Institute

Key \& Key Communications

gabriellaklein@gabriellaklein.eu

ORCID: 0000-0002-2821-2254

\section{NOAH JOHNSTON}

Teaching Assistance Program in France

noah.t.johnston@gmail.com

ORCID: 0000-0001-8500-2029 


\section{JOEL JOHNSTON}

Let Me Learn

jjohnston@letmelearn.org ORCID: 0000-0001-9875-3542 